DOI: https://doi.org/10.18524/2519-2523.2021.16.245747

УДК 94(477.7=161.3)«1917/1919»

\title{
THE STATE OF RESEARCH OF THE HISTORY OF BELARUSIANS IN THE SOUTH OF UKRAINE IN THE REVOLUTIONARY ERA: AN OVERVIEW OF MODERN PUBLICATIONS
}

\section{Liudmyla Novikova}

$\mathrm{PhD}$ (History), Associate Professor

Odesa I. I. Mechnikov National

University

2, Dvoryanska Str., Odesa, 65082,

Ukraine

ORCID: https://orcid.org/0000-0003-

4764-7867

E-mail:

lyudmilanovikova@hotmail.com

Citation: Novikova, L. (2021) The state of research of the history of Belarusians in the south of Ukraine in the revolutionary era: an overview of modern publications. Chornomors' $k a$ mynuvshyna, vol. 16, pp. 119-124.

Submitted: 12.12 .2021

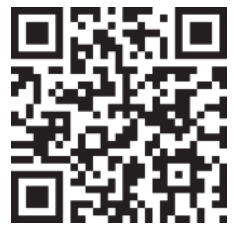

\section{Annotation}

The article is devoted to the analysis of contemporary Ukrainian, Belarusian and Polish historiography of the history of Belarusians in the south of Ukraine and in Odesa and the district during the Ukrainian National-Democratic Revolution. The scientific relevance of the problem of research is associated with an insufficient level of its research in Ukrainian historiography. This aspect was chosen with taking into account the fact that during the Ukrainian National Democratic Revolution of 1917-1920 the territory of Southern Ukraine, mainly the city of Odesa and the district, due to economic ties and its political significance, became an important region for concentration of Belarusians, their trade activities, participation in political life and national state construction, etc. Of particular interest are the researches of $M$. Schavlinskiy, D. Mikhalyuk, O. Zubko. The researchers from Odesa are represented insufficiently. Researchers address such important problems as the creation of the Belarusian National Council in Odesa, the Belarusian National Commissariat and the Consulate, the activities of Belarusian national organizations. Most of the research examines the history of Belarusians in the south of Ukraine and the city of Odesa in the context of studying other problems. As a result of the study, it was found that in modern historiography - Ukrainian, Belarusian, Polish - some aspects of the history of Belarusians in the south of Ukraine, mainly in Odesa and the district, were covered for the period of 1917-1919.The researches are as special as and more general, in which events in the region are mentioned briefly in the context of a wider problem related mainly to the Belarusian national movement and the Belarusian state construction. As a rule, the investigators are limited only to mentions of personalities, or briefly characterize the Odesa period of their biographies. Further research requires the problem of interaction between the Belarusian ethnic group in the population of Odesa and in the south of Ukraine in the early XX century and Belarusian refugees during World War I, also Belarusian cultural and educational activities in the south mentioned in the research literature, etc.

Key words: Belarusians in Odesa and the south of Ukraine in 1917-1919; contemporary Belarusian historiography; contemporary Ukrainian historiography; contemporary Polish historiography; S. Nekrashevich; K. Sapiezhko. 


\section{СТАН ДОСЛІДЖЕННЯ ІСТОРІЇ БІЛОРУСІВ НА ПІВДНІ УКРАЇНИ У РЕВОЛЮЦІЙНУ ДОБУ: ОГЛЯД СУЧАСНИХ ПУБЛІКАЦІЙ}

\section{Людмила Новікова}

Кандидат історичних наук, доцент Одеський національний університет імені I. I. Мечникова

Вул. Дворянська, 2, Одеса, 65082, Україна

ORCID: https://orcid.org/0000-00034764-7867

E-mail: lyudmilanovikova@hotmail.com

Цитування: Новікова Л. Стан дослідження історії білорусів на півдні України у революційну добу: огляд сучасних публікацій. Чорноморська минувшина: записки Відділу історії козацтва на півдні України: зб. наук. пр. / за. ред. В. А. Смолія. Одеса: ФОП Бондаренко М.О., 2021. Вип. 16.

C. 119-124.

Отримано: 12.12.2021

\section{Анотація}

В огляді сучасних українських, білоруських та польських публікачій, присвячених білорусам на півдні Украйни та м. Одесі в 1917-1919 рр., здійснено аналіз структури досліднииької проблематики. 3 'ясовано, щуо історія білорусів у регіоні подається переважно в контексті історії білоруського національного руху та білоруського національного державотворення. Водночас було встановлено, щчо низка аспектів проблеми вимагає додаткового дослідження, в першу чергу иее стосується біографістики, а саме діяльності в регіоні окремих лідерів білоруського нащіонального руху.

Ключові слова: білоруси в Одесі та на півдні Украйни в 1917-1919 рр.; сучасна білоруська історіографія; сучасна українська історіографія; сучасна польська історіографія; С. Некрашевич; К. Сапежко.

Білоруська національна меншина в Україні має давнє походження та багатовимірну історичну спадщину. Важливою сторінкою історії білорусів в Україні $\epsilon$ період Української національно-демократичної революції 1917-1920 рр. У цей час територія Південної України й Одеса, зокрема, завдяки економічним зв'язкам та своєму політичному значенню, стала важливим регіоном концентрації білорусів, здійснення ними торговельної діяльності, участі у політичному житті та національному державному будівництві тощо. Ці питання знайшли висвітлення у сучасній українській, білоруській та польській історичній літературі. Більша частина досліджень розглядає історію білорусів на півдні та м. Одеса в контексті вивчення інших проблем. Водночас окремі дослідники висвітлюють цю проблематику як спеціальну.

Певна увага в історіографії приділяється демографічному аспекту історії білорусів в Україні в цей період, що дозволяє висвітлити швидке зростання кількості білорусів в Україні, формування тим самим бази для розвитку білоруського національного руху у регіонах їх концентрації, у тому числі в Одесі. Значну роль у переміщені населення зіграла Перша світова війна, на що вказує, зокрема, М. Щавлінський. Він, а також польська дослідниця Д. Міхалюк [8, с. 25; 6, с. 47] надають статистику і зазначають, що в “Одеській окрузі” білорусів нараховувало близько 100 тисяч, а в Одесі й поблизу міста - близько 20 тисяч.

Частина дослідників висвітлює історію білорусів на півдні України та в Одесі, зокрема, у контексті білоруського національного державотворення у 1918 р., у зв'язку зі спробами дипломатичних делегацій та спільних комісій вирішити питання налагодження економічних міждержавних українсько-білоруських зав'язків, відкриття представництв, консульств (які були відкриті в Києві та Одесі), а також добитися міжнародного визнання БНР, в тому числі 3 боку українських національних держав. Саме подібне висвітлення південноукраїнської проблематики ми зустрічаємо у роботі білоруського дослідника О. Кукси. Серед іншого, автор звертає увагу на те, що важливим аспектом білорусько-українських контактів в 1918 р. було налагодження товарообміну, вказує на роль Центральної торговельної палати у Києві (була відкрита 26 квітня 1918 р.), яка мала також захищати інтереси білоруських організацій та громадян на всій території України), на існування торговельної палати в Одесі [4, с. 62]. 
У цьому ж контексті знаходиться інформація щодо білорусів в Україні та Одесі у праці польської дослідниці Д. Міхалюк [6, с. 38-40]. Окремо вона розглядає рівень збереження джерел з історії дипломатичних місій БНР у 1918-1919 pp. у Національному архіві Республіки Білорусь. Серед іншого, дослідниця згадує про наявність архівного фонду Національної білоруської організації "Гай” в Одесі [6, с. 43]. Водночас вона відзначає, що доля архіву Консульства БНР в Одесі залишається невідомою [6, с. 47].

Окремим аспектом вивчення є діяльність консульства в Одесі (Д. Міхалюк називає його «представництвом БНР в Одесі» [6, с. 39]. Поява консульства, на думку дослідниці, була пов'язана 3 такими моментами, як концентрація білоруських біженців в Одесі, колишніх військовослужбовців з Румунського фронту. Вибори консула в Одесі в серпні 1918 р., посаду якого зайняв С. Некрашевич, О. Кукса розглядає як прояв активності білорусів в Україні [4, с. 63]. Так само високо цей дослідник оцінює діяльність консульства у 1919 р., на тлі ліквідації білоруських установ в Україні та дипломатичних місій при зайнятті території Білорусі радянськими військами. Кукса відзначає, що у 1919 р. Одеське консульство було "єдиним активним центром білоруського руху» в Україні [4, с. 64]. О. Зубко наводить прізвища «місцевих білоруських діячів», які пропонувалися на пост консула: “Некрашевич - местный белорусский деятель; Карташов - бывший председатель Витебской губернской земской управы; Трофимов и Балицкий - местные белорусские деятели” [3, с. 90].

Д. Міхалюк згадує також діяльність політичного авантюриста Олександра Бахановича, який у Парижі на конференції у 1919 р. представляв себе як керівника Тимчасового Білоруського Уряду, створеного в Одесі. За висновкам дослідниці, він був третім, хто хотів представляти білоруські інтереси на Паризькій конференції (після Луцкевича та Ластовського). Д. Міхалюк повністю заперечує те, що Баханович був пов'язаний 3 Білоруським комісаріатом в Одесі [6, с. 47-48]. Спеціальні дослідження ми маємо в роботах О. Зубка [3], М. Щавлінського [8], Т. Вінцковського [2].

Докладний розгляд активізації білоруського національного руху серед білорусів в Одесі здійснений у дослідженні М. Щавлінського "Белорусские организации в 1917-1918 гг. в Одессе” (1996). Автор вважає, що Білоруська військова рада, створена на з'їзді військовихбілорусів Румунського фронту 1-7 грудня 1917 р., а також товариство “Білоруський гай” в Одесі були найбільш впливовими серед інших національних організацій [8, с. 25].

Він послідовно розглядає питання концентрації білорусів на півдні та Одесі під час Першої світової війни, поєднання постійно проживаючих білорусів з біженцями у вирішенні національних питань, створення національних товариств, Білоруської Національної Ради 3 50 чоловік на чолі з професором Сапожко. Дослідник відзначає, що ii виконавчим органом став створений раніше комісаріат, простежує дії комісаріату, направлені до його легітимізації [1, с. 25-26], у тому числі з боку Народного Секретаріату Білоруської Народної Республіки (БНР). М. Щавлінський відзначає, що мета створених органів - самовизначення Білорусі та захист білорусів в Одеському окрузі, наводить характеристику роботи, яку проводили Рада, Комісаріат. Зокрема, Комісаріат мав виконувати функції представництва БНР перед урядом України на правах консульства до створення консульства БНР в Одесі, здійснював реєстрацію білорусів, кожному видавалося посвідчення білоруською та українською мовами, добивався права національно-персональної автономії для білорусів в Україні тощо. При цьому дослідник вказує на те, що комісаріат перебільшував в оцінці кількості білорусів в Україні представники комісаріату називали цифру близько мільйона чоловік. М. Щавлінський вказує, що фактично білоруси змогли зібрати всього сім тисяч підписів замість 10 тисяч, необхідних для отримання прав за законом про національно-персональну автономію [1, с. 26]. Окрему характеристику М. Щавлінський надає діяльності комісаріату у військовій сфері, де зазначає, що діяльність білоруського комісаріату продовжувалась в Одесі до відкриття консульства БНР у вересні 1918 р. [1, с. 27]. Докладні відомості щодо напрямів діяльності Комісаріату надає у 
своїй роботі і Д. Міхалюк, зокрема, про намір формувати білоруські національні загони на території України. Головною політичною метою Комісаріату Д. Міхалюк називає “визнання незалежності Білорусі” [2, с. 47].

О. Зубко, розглядає створення 6 березня 1918 р. на спільному засіданні Білоруської військової ради та товариства "Білоруський гай” “Білоруський національний комісаріат, який має бути виділений з Одеських білоруських організацій” [4, с. 88]. На відміну від М. Щавлінського, цей дослідник останні відомості про їх діяльність Одеського відносить до квітня 1919 р. [4, с. 92].

Значення південноукраїнського регіону у модерному національному розвитку білорусів розглядається у сучасній білоруській історіографії і у контексті історії та історіографії історії білоруських секцій РКП(б). Так, С. Сіняк вказує на те, що білоруські секції РКП(б), хоча й існували недовго відіграли помітну роль в історії національно-культурної й національнодержавної розбудови Білорусі у 1918-1919 рр. [7, с. 11]. Одним із джерел інформації цього автора була робота українського дослідника М. Сапуна (1986р.), який вперше довів існування окремих національних білоруських секцій при парторганізаціях України та з'ясував, що при Одеському губкомі КП(б)У у березні 1920 р. була створена і проіснувала три дні, до об'єднання з литовською, окрема білоруська секція, яка і надалі практично була самостійною у культурно-освітній сфері [7, с. 14]. С. Сіняк виявив серед документів Центрального бюро литовсько-білоруських секцій РКП(б) протоколи секції та доповіді ії активного учасника П. В. Ільючонка. Ці матеріали, за висновком автора, містять інформацію щодо різних аспектів діяльності секції.

Український дослідник Т. Вінцковський приділяє спеціальну увагу білорусам на півдні України у зв'язку з дослідженням регіональних особливостей Української національнодемократичної революції. Окремий інтерес, з погляду історика, являла ситуація в Таврійській губернії, що визначалася найбільш поліетнічним характером населення, порівняно 3 іншими визначеними Центральною Радою українськими губерніями. Тому становище місцевих національних громад під час революції є важливою проблематикою спеціального дослідження [2, с. 101]. Автор розглядає період першої половини 1917 р., до проведенні виборів у місцеві органи самоврядування. Свій аналіз Т. Вінцковський основує на матеріалах місцевого видання “Южные ведомости". Більшість матеріалів газети розкривали суспільну активність українського та польського населення. Як зазначає автор, інформація щодо білорусів має обмежений характер у вигляді однісї статті в травні 1917 р., в якій йшлося про створення у Сімферополі білоруської організації. Така інформаційна ситуація, на думку Т. Вінцковського, свідчить “про вкрай помітну пасивність окресленої етнічної групи” [2, с. 104].

Практично відсутні в історіографії дослідження спеціального біографічного характеру, які б розкривали діяльність білорусів, учасників білоруського національного руху на півдні та м. Одеса. Література щодо ряду персоналій малодоступна для ознайомлення в Україні, тому що дослідження проводяться переважно білоруськими вченими, відсутні електронні публікації. Існуючі праці головним чином побіжно висвітлюють одеський період біографії того чи іншого діяча. Зокрема, це стосується постаті С. Некрашевича (1883-1937). Як правило, вчені звертаються до його біографії як відомого ініціатора заснування та голови Інституту білоруської культури, першого директора Інституту мовознавства тощо. Певний інтерес у такій історіографічній ситуації являють деякі публіцистичні статті, зокрема, за авторством А. Ляукович (О. Левкович). Вона посилається на автобіографію С. Некрашевича, працю Е. Іоффе, очевидно, його статтю “Першы старшыня Інбелкульту” (Спадчына, 1995, № 6). У статті А. Ляукович, зокрема, вказується на те, що С. Некрашевич був учасником Першої світової війни, провів в Одесі білоруську воєнну конференцію. Цікавою є згадка про те, що у жовтні 1918 р. газета “Дзянніца" повідомляла, що, завдяки зусиллям С. М. Некрашевича, в Одесі було відкрито “30 початкових білоруських шкіл та білоруська змішана гімназія у складі перших чотирьох класів”. Крім того, авторка статті згадує про те, що С. Некрашевич очолював білоруську секцію при губвідділі наросвіти. Вона також цитує дані Е. Іоффе, згідно з якими С. Некрашевич 13 січня 1919 р. звернувся до командуючого військами Антанти Бертело 3 
меморандумом про створення Білоруської західної армії, що мала діяти проти більшовиків (планував залучити 40 тис. осіб) (не було здійснено). У 1920 р. С. Некрашевич переїжджає до Мінська [5].

Подібна ситуація і в історії вивчення постаті голови Білоруської Національної Ради в Одесі, названого одним з авторів “професор Сапожко". Мова, ймовірно, йде про відомого в Одесі на початку XX ст. вченого - К. Сапежка (1857-1928), який з 1902 р. був призначений професором Новоросійського університету по кафедрі хірургічної університетської клініки, а у 1914 р. був затверджений на посаді заслуженого професора [1, с. 9].

Отже, у сучасній історіографії - українській, білоруській, польській - висвітлюються окремі аспекти історії білорусів на півдні, головне в Одесі та окрузі, у 1917-1919 pp. Дослідження мають як спеціальний характер, так і більш загальний, у яких події в регіоні згадуються побіжно в контексті більш широкої проблематики, пов'язаної переважно 3 національним білоруським рухом та державним будівництвом. Незважаючи на певні здобутки історіографії проблеми, відчувається брак спеціальних досліджень біографічного характеру дослідники, як правило, обмежуються тільки згадками про персоналії, або коротко характеризують одеський період їх біографії. Подальшого дослідження потребує проблема взаємовпливів між білоруською етнічною групою в населенні Одеси та на півдні на початку XX ст. та білоруськими біженцями під час Першої світової війни, згадана в дослідницькій літературі білоруська культурна та освітня діяльність на півдні тощо.

\section{Джерела та література:}

1. Васильев К. К. Кирилл Михайлович Сапежко (к 150-летию со дня рождения). Вестник хирургии. 2007. № 10. С. 9-10.

2. Вінцковський Т.С. Вплив революції 1917 р. на консолідацію української, польської і білоруської громад Таврійської губернії (за матеріалами газети “Южные ведомости”). Україна: культурна спадщина, нащіональна свідомість, державність. Львів, 2008. Вип. 17. С. 101-105.

3. Зубко О. І. Білоруський національний комісаріат в Одесі (1918-1919 pp.). Наукові записки [Вінницького державного педагогічного університету імені Михайла Коцюбинського. Серія: Історія. 2010. Вип. 18. С. 88-93. URL: http://nbuv.gov.ua/UJRN/Nzvdpu_ist_2010_18_20

4. Кукса А. Н. Белорусско-украинские дипломатические контакты (январь-декабрь 1918 г.). Журнал международного права и международных отношений. 2006. № 1. С. 61-65. URL: http://elib.bsu.by/handle/123456789/23774

5. Ляукович А. Степан Некрашевич. Руплівец мовы. Звязда. 2019. 6 люты. URL: https://zviazda.by/ru/news/20190206/1549442549-stepan-nekrashevich-rachitel-yazyka

6. Міхалюк Д. Дипломатичні архіви Білоруської Народної Республіки 1918-1921 років як джерело вивчення білорусько-польських та білорусько-українських відносин. Спеціальні історичні дисципліни: питання теорії та методики. 2017. Число 28. С. 33-49. URL: http://resource.history.org.ua/publ/sidptm_2017_28_5

7. Сіняк С. А. Беларускія секцы РКП(б): крыніцазнаўчы аспект. Веснік Беларускага дзяржаўнага універсітэта. Сер. 3: Гісторыя. Філасофія. Псіхалогія. Паліталогія. Сацыялогія. Эканоміка. Права. 2012. № 2. C.11-15. URL: http://elib.bsu.by/hndle/123456789/45234

8. Щавлинский Н. Б. Белорусские организации в 1917-1918 гг. в Одессе. Веснік Беларускага дзяржайнага універсітэта. Серыя 3, Гісторыя. Філасофія. Паліталогія. Сацыялогія. Эканоміка. Права. Мінск: Універсітэцкае, 1996. № 1. С. 24-27. URL: https://elib.bsu.by/handle/123456789/253182 


\section{References:}

1. Vasil'ev, K. K. (2007) Kirill Mikhajlovich Sapezhko (k 150-lietiiu so dnia rozhdieniia) [Kirill Mikhajlovich Sapezhko (to 150 annyversary)]. Vestnik khirurgii. 2007.№ 10. 9-10. [in Russian].

2. Vintskovs'kyi, T. S. (2008) Vplyv revolutsii 1917 r. na consolidatsiyu ukrains'koi, pols'koi i bilorus'koi gromad Tavriyskoi gubernii (za materialamy gazety "Yuzhnyie vedomosti" [Influence of the revolution of 1917 on the consolidation of Ukrainian, Polish and Belarusian communities in Tavriyskaya province (according to the newspaper "Southern news")]. Ukraina: kulturna spadschyna, natsionalna svidomist', derzhavnist'. Lviv, 2008. Vyp. 17. 101-105. [in Ukrainian].

3. Zubko, O. I. (2010) Bilorus'kyi natsional'nyi comisariat v Odesi (1918-1919) [Belarusian national commissariat in Odesa (1918-1919)]. Naukovi zapysky [Vinnyts'kogo derzhavnogo pedagogichnogo universytetu]. Seriia: Istoriya. 2010. Vyp. 18. 88-93. [in Ukrainian].

4.Kuksa, A. N. (2006) Belorussko-ukrainskiye diplomaticheskiye kontakty (ianvar'-dekabr' 1918 g.) [Belarusian-Ukrainian diplomatic contacts (January-December 1918]. Zhurnal mezhdunarodnogo prava imezhdunarodnykh otnoshenij. 2006. № 1. 61-65. [in Russian].

5. Liaukovich, A. (2019) Stepan Nekrashevich. Ruplivets movy [Stepan Nekrashevich. Fighter for language]. Zviazda. 2019. 6 February. [in Belarusian].

6. Mikhaliuk, D. (2017) Dyplomatychni arkhivy Bilorus'koyi Narodnoyi Respubliky 19181921 rokiv yak dzherelo vyvchennia bilorus'ko-pol's'kykh ta bilorus'ko-ukrains'kykh vidnosyn [Diplomatic archives of the Belarusian People's Republic of 1918-1921 as a source for study of Belarusian-Polish and Belarusian-Ukrainian relations]. Spetsial'ni istorychni dystsypliny: pytannia teorii ta metodiky. 2017. №28. 33-49. [in Ukrainian].

7. Siniak, S. A. (2012) Belaruskiya sektsyi RKP(b): krynitaznavchy aspect [Belarusian section of RCP(b): source research]. Vesnik Bielaruskaga dziarzhavnaga universiteta. Ser. 3. 2012. № 2. 1115. [in Belarusian]

8. Schavlinskiy, N. B. (1996) Bielorusskiye organizatsii v 1917-1918 gg. v Odiesie [Belarusian organizations in 1917-1918 in Odesa]. Vesnik Bielaruskaga dziarzhavnaga universiteta. Ser. 3. 1996. № 1. 24-27. [in Russian]. 